\title{
Validitas Lingkar Lengan Atas Mendeteksi Risiko Kekurangan Energi Kronis pada Wanita Indonesia
}

\author{
Validity Mid-Upper Arm Circumference to Detect Chronic Energy \\ Malnutrition Risk of Indonesian Women
}

Diny Eva Ariyani* Endang L. Achadi* Anies Irawati**

*Departemen Gizi Kesehatan Masyarakat Fakultas Kesehatan Masyarakat Universitas Indonesia, **Pusat
Teknologi Intervensi Kesehatan Masyarakat Balitbangkes Kementerian Kesehatan Republik Indonesia

\begin{abstract}
Abstrak
Lingkar lengan atas (LiLA) telah digunakan sebagai indikator proksi terhadap risiko kekurangan energi kronis (KEK) untuk ibu hamil di Indonesia karena tidak terdapat data berat badan prahamil pada sebagian besar ibu hamil. Selama ini, ambang batas LiLA yang digunakan adalah $23,5 \mathrm{~cm}$. Penelitian ini bertujuan untuk menguji validitas LiLA terhadap indeks massa tubuh (IMT) yang merupakan indikator yang lebih baik untuk mengetahui status gizi wanita dewasa. Penelitian ini menggunakan data Riset Kesehatan Dasar tahun 2007 pada perempuan dewasa usia 20 - 45 tahun di seluruh Indonesia. Hasil penelitian ini ialah ambang batas LiLA yang paling optimal untuk mendeteksi risiko KEK di Indonesia berada pada titik $24,95 \mathrm{~cm}(\mathrm{Se}=85 \%$; Sp $=75 \%)$. Terdapat perbedaan ambang batas antarprovinsi tetapi tidak lebih dari $2 \mathrm{~cm}$, terendah di Provinsi Nusa Tenggara Timur $(23,95 \mathrm{~cm})$ dan tertinggi di Provinsi Sulawesi Utara dan Gorontalo $(25,95 \mathrm{~cm})$. LiLA mempunyai korelasi yang kuat $(r=0,67$; nilai $p<0,000)$ dengan IMT. Direkomendasikan untuk menggunakan ambang batas LiLA 24,95 cm untuk mendeteksi risiko KEK wanita usia 20 - 45 tahun, sementara $23,5 \mathrm{~cm}$ untuk outcome kehamilan, yaitu morbiditas dan mortalitas bayi. Kata kunci: Lingkar lengan atas, indeks massa tubuh, kekurangan energi kronis
\end{abstract}

\footnotetext{
Abstract

Mid-upper arm circumference has been used in Indonesia as an proxy indicator of chronic energy malnutrition risk for pregnant women because there isn't any data of prepregnancy weight in most of pregnant women. The boundary used was $23,5 \mathrm{~cm}$. The objective of the study is to validate the current boundary related to body mass index (BMI) indicator, which is believed as a better indicator in identifying women nutritional status. The study is using Riset Kesehatan Dasar 2007 data on Indonesian adult women aged $20-45$ years old. The study found the boundary is $24,95 \mathrm{~cm}$ for detecting chronic energy malnutrition risk among adult women ( $\mathrm{Se}=85 \%$; $\mathrm{Sp}=75 \%$ ). There are differences among provinces but not more than $2 \mathrm{~cm}$, the lowest
}

is in Nusa Tenggara Timur $(23,95 \mathrm{~cm})$ and the highest is in North Sulawesi and Gorontalo $(25,95 \mathrm{~cm})$. Mid upper arm circumference has a strong relation to $\mathrm{BMI}(r=0,67 ; p$ value $<0,000)$. It is recommended to use mid-upper arm circumference boundary $24,95 \mathrm{~cm}$ to detect chronic energy malnutrition on 20 - 45 years old women and $23,5 \mathrm{~cm}$ to pregnancy outcome, baby morbidity, and mortality.

Key words: Mid-upper arm circumference, body mass index, chronic energy deficiency

\section{Pendahuluan}

Berbagai penelitian membuktikan bahwa gizi berperan sebagai faktor penentu utama kualitas sumber daya manusia, terutama sejak 1.000 hari pertama kehidupan, pada masa kehamilan sampai usia bayi 2 tahun. Peran penting gizi pada masa kehamilan membuat status gizi ibu hamil mendapat perhatian yang besar. Status kekurangan energi kronis (KEK) sebelum hamil memengaruhi pertumbuhan janin dan menjadi pertimbangan capaian peningkatan berat selama kehamilan. Di Indonesia, berat badan prahamil umumnya tidak diketahui sehingga lingkar lengan atas (LiLA) dijadikan indikator risiko KEK pada ibu hamil. Sampai sedemikian jauh, ambang batas yang digunakan untuk menentukan seorang ibu hamil berisiko KEK adalah $23,5 \mathrm{~cm} .{ }^{1}$

KEK dapat dialami wanita usia subur (WUS) usia 15 - 45 tahun sejak remaja kemudian berlanjut pada masa kehamilan dan menyusui akibat cadangan energi dan zat gizi yang rendah. ${ }^{1,2}$ Salah satu dampak jangka panjang

Alamat Korespondensi: Diny Eva Ariyani, Departemen Gizi Kesmas FKM Universitas Indonesia, Gd. F Lt. 2, Kampus Baru UI Depok 16424,

Hp.087772345712, e-mail: dinyeva90@gmail.com 
masalah gizi makro pada WUS dan ibu hamil dengan KEK adalah melahirkan bayi dengan berat badan lahir rendah (BBLR). Ibu yang mengalami KEK berisiko melahirkan bayi BBLR 4,8 kali lebih besar daripada ibu yang tidak mengalami KEK. ${ }^{3}$ Setiap tahun, diperkirakan sekitar 350.000 bayi lahir dengan BBLR $\leq 2.500$ gram yang merupakan salah satu penyebab utama angka gizi kurang dan kematian balita. ${ }^{4}$ Untuk menanggulangi dan mengurangi kelahiran bayi BBLR perlu langkah yang lebih dini antara lain melakukan deteksi WUS berisiko KEK sejak dini. ${ }^{5}$ Di negara berkembang, prevalensi KEK pada wanita hamil mencapai $41 \% .6$ Pada tahun $2003 \mathrm{di}$ Asia, proporsi KEK Thailand sekitar 15,3\%. ${ }^{7}$ Berdasarkan pengukuran LiLA, prevalensi nasional KEK di kalangan WUS adalah $14,8 \%$ dengan jumlah penderita sekitar 30 juta jiwa. ${ }^{4}$

Food and Agriculture Organization (FAO)/World Health Organization (WHO)/United Nation University (UNU) menentukan batasan berat badan normal terhadap tinggi badan orang dewasa berdasarkan nilai indeks massa tubuh (IMT)/body mass index (BMI). IMT dihitung berdasarkan berat badan dalam kilogram $(\mathrm{kg})$ dibagi dengan tinggi badan dalam meter kuadrat $\left(\mathrm{m}^{2}\right)$ dan tidak terikat dengan jenis kelamin. Di berbagai negara, ambang batas IMT yang digunakan merujuk ketentuan FAO/WHO. ${ }^{8}$ Penggunaan IMT hanya dapat berlaku pada usia dewasa ( $>18$ tahun) dan tidak sedang hamil. Penggunaan IMT pada remaja dipengaruhi oleh umur sehingga pengukuran yang dapat dilakukan adalah indeks massa tubuh per usia (IMT/U). ${ }^{9}$ Selain itu, pengukuran status gizi pada WUS dapat dilakukan dengan menggunakan LiLA, tetapi LiLA bukan cara pengukuran status gizi yang ideal sebab perubahan LiLA memerlukan waktu lama. Kelemahan lain, LiLA tidak dapat digunakan untuk memantau perubahan status gizi jangka pendek sehingga pengukuran LiLA tidak dapat dijadikan alat pemantau status gizi. 1,10

Pada ibu hamil, LiLA yang digunakan pada pengukuran KEK dengan metode IMT tidak dapat dilakukan. Nilai LiLA relatif statis sehingga interpretasi LiLA lebih rendah daripada nilai rekomendasi yang mengindikasikan status KEK sehingga dinyatakan bukan KEK. LiLA terutama bermanfaat untuk mengetahui risiko KEK pada awal kehamilan karena berat badan prahamil tidak diketahui. KEK merupakan prediktor penting prognosis ibu hamil. Di Indonesia, para ibu tidak biasa menimbang berat badan sebelum hamil sehingga penggunaan LiLA sebagai indikator risiko KEK menjadi sangat penting. LiLA dapat lebih mudah mendeteksi KEK daripada IMT sehingga dapat dilakukan oleh masyarakat awam. ${ }^{1,11}$

Indonesia menetapkan ambang batas IMT yang dimodifikasi berdasarkan pengalaman klinis dan penelitian di beberapa negara berkembang. Ambang batas IMT kategori normal yang digunakan untuk penduduk Indonesia adalah $18,5-25,0 \mathrm{~kg} / \mathrm{m}^{2}{ }^{12}$ Pengukuran LiLA juga telah digunakan secara umum di Indonesia. Ambang batas LiLA yang digunakan adalah $23,5 \mathrm{~cm}$. Namun sampai kini, ambang batas LiLA yang digunakan di Indonesia belum diuji secara memadai. ${ }^{13}$ Selain itu, penentuan ambang batas $23,5 \mathrm{~cm}$ lebih ditujukan pada risiko dan mortalitas bayi, bukan ibu.

Di Brazil pada tahun 1988 pernah dilakukan uji validitas ambang batas LiLA untuk mendeteksi risiko bayi BBLR. Khusus untuk ambang batas $23,5 \mathrm{~cm}$ pernah dilakukan uji sensitivitas (Se) dan spesifisitas (Sp) oleh Lechtig. Hasil dari penelitian tersebut menunjukkan bahwa bayi BBLR diprediksi dengan nilai $\mathrm{Se}=77 \%$ dan $\mathrm{Sp}$ $=71 \% .{ }^{14} \mathrm{Di}$ Indonesia pernah dilakukan penelitian serupa yakni di Indramayu, Jawa Barat dengan sampel penelitian 94 orang. Dengan hasil LiLA pada batas 23,5 $\mathrm{cm}, \mathrm{Se}=42,6 \%$ dan $\mathrm{Sp}=64,4 \% .{ }^{15}$ Nilai Se dan Sp LiLA $23,5 \mathrm{~cm}$ tersebut tergolong rendah sehingga kemungkinan ambang batas LiLA dengan validitas optimal untuk orang Indonesia berbeda dengan yang digunakan saat ini. Namun, sampel penelitian tersebut belum cukup representatif bagi seluruh penduduk Indonesia karena hanya diambil dari satu kabupaten di satu provinsi di Indonesia.

Penelitian terkait ambang batas LiLA di berbagai negara memberikan hasil yang berbeda-beda. Penelitian di India mendapat hasil ambang batas $24,3 \mathrm{~cm}$ dan $23,9 \mathrm{~cm}$ merupakan indikator terbaik yang menunjukkan IMT < $18,5 \mathrm{~kg} / \mathrm{m}^{2}$ atau KEK. Penelitian tersebut menyimpulkan bahwa terdapat hubungan antara ambang batas LiLA dengan IMT. ${ }^{11}$ Di Nigeria, ambang batas yang digunakan di bagian utara adalah $23 \mathrm{~cm}$, sedangkan di bagian sela$\tan 24 \mathrm{~cm}$. Namun, secara umum ambang batas $24 \mathrm{~cm}$ merupakan nilai optimal untuk mendeteksi KEK di Nigeria. ${ }^{16}$

Penelitian ini bertujuan untuk mencari ambang batas ukuran LiLA yang mempunyai validitas paling optimal terhadap IMT dalam mendeteksi risiko kekurangan energi kronis pada WUS di seluruh Indonesia. Mengingat Indonesia terdiri dari banyak pulau dan mempunyai 33 provinsi dengan beragam etnik dan suku yang memungkinkan perbedaan ambang batas LiLA pada setiap provinsi maka analisis ambang batas ini juga dilakukan untuk setiap provinsi di Indonesia.

\section{Metode}

Penelitian ini menggunakan sumber data sekunder Riset Kesehatan Dasar (Riskesdas) pada tahun 2007 2008 tentang status gizi usia $\geq 15$ tahun. Desain penelitian Riskesdas adalah cross sectional. Variabel yang diamati pada penelitian ini meliputi umur, berat badan, tinggi badan, LiLA, dan IMT WUS (20 - 45 tahun). Studi Riskesdas dilakukan pada bulan Agustus 2007 sampai dengan Januari 2008 di seluruh provinsi di Indonesia 
mencakup 440 kabupaten/kota (dari jumlah keseluruhan 456 kabupaten/kota).

Populasi penelitian adalah wanita berusia $15-45$ tahun yang terpilih dalam sampel Riskesdas tahun 2007. Sampel penelitian adalah wanita usia 20 - 45 tahun yang menjadi responden dalam penelitian Riskesdas 2007, pada saat pengukuran tidak sedang hamil, dan data terisi secara lengkap. Jumlah sampel yang disertakan adalah 62.923 orang dengan kekuatan uji (1- $\beta$ ) lebih dari $99,99 \%$. Variabel yang diamati meliputi umur, berat badan, dan tinggi badan untuk menilai IMT, serta LiLA. Variabel tersebut diambil dari kuesioner RKD 07. IND Blok XI dan RKD 07. RT Blok I dan IV. Analisis validitas ambang batas ukuran LiLA untuk mendeteksi risiko KEK dilakukan berdasarkan nilai sensitivitas dan spesifitas ambang batas ukuran LiLA terhadap ambang batas IMT yang pada penelitian ini dijadikan gold standard.

Selanjutnya, hubungan analisis sensitivitas dan spesifisitas pengukuran ditampilkan dalam bentuk kurva yang disebut kurva Receiver Operating Characteristic (ROC) dan Area Under Curve (AUC). Kurva ROC adalah sebidang tes sensitivitas pada koordinat y dan False Positive Rate (FPR) pada koordinat x. ${ }^{17}$ Secara singkat, kurva ROC menggambarkan hubungan sensitivitas dan FPR. ${ }^{18}$ Kurva ROC yang dihasilkan disebut kurva empiris yang merupakan metode efektif untuk mengevaluasi kualitas atau kinerja uji diagnostik. ${ }^{17,19}$ Kurva ROC menampilkan kepekaan dan FPR di semua tingkat kemungkinan ambang batas sehingga dapat digunakan untuk menilai kinerja tes independen ambang batas keputusan. ${ }^{18}$

Kurva AUC merupakan salah satu ukuran yang berhubungan paling populer dengan kurva ROC. AUC adalah ukuran gabungan sensitivitas dan spesifisitas yang merupakan ukuran keseluruhan kinerja tes diagnostik yang diinterpretasikan sebagai rata-rata nilai sensitivitas untuk semua kemungkinan nilai spesifisitas. ${ }^{19}$ Nilai AUC terentang antara 0 dan 1 karena sumbu $\mathrm{x}$ dan y mempunyai nilai mulai dari 0 sampai 1. Jika nilai AUC mendekati 1, kinerja keseluruhan tes diagnostik semakin baik dan tes dengan nilai $\mathrm{AUC}=1$ berarti kinerja sangat akurat. ${ }^{17}$

\section{Hasil}

Wanita yang disertakan pada penelitian ini rata-rata berusia 32 tahun dengan rata-rata berat badan $=53,47$ $\mathrm{kg}$, tinggi badan $=152,45 \mathrm{~cm}$, ukuran LiLA $=26,52 \mathrm{~cm}$, dan IMT $=22,99 \mathrm{~kg} / \mathrm{m}^{2}$ (Tabel 1$)$.

Sekitar $6,7 \%$ wanita usia $20-45$ tahun di Indonesia mengalami KEK (IMT $<18,5 \mathrm{~kg} / \mathrm{m}^{2}$ ). Empat belas provinsi dari seluruh provinsi di Indonesia mempunyai prevalensi KEK di bawah angka prevalensi nasional $(13,6 \%)$. Provinsi tersebut meliputi Jawa Timur $(6,9 \%)$, Sulawesi Barat $(7,1 \%)$, Lampung $(7,3 \%)$, Sulawesi
Selatan $(7,4 \%)$, Kalimantan Barat $(7,4 \%)$, Maluku $(7,5 \%)$, Papua Barat $(7,6 \%)$, Nusa Tenggara Barat $(7,6 \%)$, Daerah Khusus Ibu Kota (DKI) Jakarta (7,6\%), Jawa Tengah $(8,2 \%)$, Banten $(8,5 \%)$, Daerah Istimewa (DI) Yogyakarta $(9,1 \%)$, Kalimantan Selatan $(9,9 \%)$, dan Nusa Tenggara Timur $(12,8 \%)$.

Berdasarkan LiLA, sekitar 12,4\% wanita usia 20 - 45 tahun di Indonesia berisiko KEK ( LiLA $<23,5 \mathrm{~cm}$ ). Berdasarkan analisis LiLA tersebut terdapat 12 provinsi dengan prevalensi wanita berisiko KEK di bawah dan di atas angka nasional. Provinsi tersebut meliputi Sulawesi Selatan (12,8\%), Banten (13,1\%), Kalimantan Selatan $(13,2 \%)$, Jawa Timur $(13,5 \%)$, Nusa Tenggara Barat $(13,8 \%)$, Maluku $(14,9 \%)$, Jawa Tengah $(15,4 \%)$, DKI Jakarta $(15,5 \%)$, DI Yogyakarta $(17 \%)$, Papua Barat $(20,1 \%)$, Papua $(21,4 \%)$, dan Nusa Tenggara Timur $(23 \%)$.

Pola hubungan antara LiLA dengan IMT adalah positif, berarti wanita dengan ukuran LiLA lebih besar mempunyai IMT yang besar pula. Hal ini berkaitan dengan komposisi pada LiLA yang terdiri dari tulang, otot, dan lemak. Pada wanita dengan ukuran LiLA yang lebih besar mempunyai komposisi lemak yang sesuai dengan komposisi tubuh. Kenaikan berat badan menyebabkan nilai IMT naik karena perhitungan IMT adalah membagi berat badan dengan tinggi badan kuadrat (Tabel 2).

Gambar 1 menunjukkan bahwa nilai AUC pengukuran LiLA untuk keseluruhan Indonesia mempunyai nilai yang baik yaitu $89 \%$ atau 0,89 . Setelah dilakukan analisis kurva ROC, dilanjutkan analisis untuk mencari ambang batas optimal untuk ukuran LiLA dalam mendeteksi risiko KEK pada wanita usia 20 - 45 tahun

Tabel 1. Distribusi Berdasarkan Umur dan Status Gizi

\begin{tabular}{lllll}
\hline Variabel & Mean & SD & Minimal & Maksimal \\
\hline Umur (tahun) & 32,30 & 7,33 & 20,00 & 45,00 \\
BB $(\mathrm{kg})$ & 53,47 & 9,23 & 26,90 & 113,4 \\
TB $(\mathrm{cm})$ & 152,45 & 5,89 & 127,50 & 178,00 \\
IMT $\left(\mathrm{kg} / \mathrm{m}^{2}\right)$ & 22,99 & 3,75 & 13,90 & 40,00 \\
LiLA $(\mathrm{cm})$ & 26,52 & 3,15 & 14,00 & 45,00 \\
\hline
\end{tabular}

Keterangan:

$\mathrm{SD}=$ Standar Deviasi

$\mathrm{BB}=$ Berat Badan

$\mathrm{TB}=$ Tinggi Badan

Tabel 2. Analisis Korelasi LiLA, IMT, BB, TB, dan Umur Wanita Usia 20 - 45 Tahun di Indonesia

\begin{tabular}{llllll}
\hline Variabel & LiLA & IMT & TB & BB & Umur \\
\hline Umur & 0,23 & 0,25 & $-0,26$ & 0,22 & 1,000 \\
BB & 0,66 & 0,87 & 0,36 & 1,000 & \\
TB & 0,07 & $-0,10$ & 1,000 & & \\
IMT & 0,67 & 1,000 & & & \\
LiLA & 1,000 & & & & \\
\hline
\end{tabular}




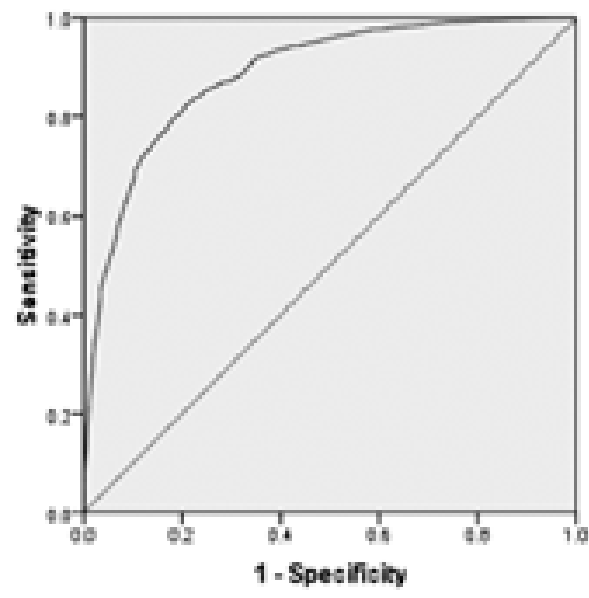

Gambar 1. Kurva ROC Lingkar Lengan Atas dalam Mendeteksi Risiko KEK di Indonesia

berdasarkan nilai sensitivitas dan spesifisitas. Pada penelitian ini diperoleh hasil bahwa ambang batas LiLA yang paling optimal dalam mendeteksi KEK adalah pada titik $24,95 \mathrm{~cm}$ dengan nilai sensitivitas $=85 \%$ dan spesifisitas $=75 \%$.

Tabel 3 memperlihatkan kedua ambang batas mempunyai kelebihan masing-masing. Ambang batas 24,95 $\mathrm{cm}$ mempunyai nilai sensitivitas yang lebih tinggi daripada ambang batas $23,5 \mathrm{~cm}$. Ambang batas 24,95 cm mempunyai kelebihan lain yakni nilai Se dan Sp yang berada pada kisaran $70 \%-90 \%(\mathrm{Se}=85 \%$ dan $\mathrm{Sp}=75 \%)$. Nilai yang termasuk dalam kategori baik dan merupakan titik yang paling optimal. Ambang batas $23,5 \mathrm{~cm}$ mempunyai nilai spesifisitas yang lebih besar daripada ambang batas $24,95 \mathrm{~cm}$.

Jumlah daerah tertinggal yang banyak di provinsi tersebut juga menandakan banyak warga yang kurang mampu memenuhi kebutuhan pangan sehari-hari. Selain itu, berdasarkan Profil Kesehatan Indonesia tahun 2009, kedua provinsi tersebut masih tergolong memiliki tingkat kesehatan yang rendah.

Selain itu, terdapat 4 provinsi dengan ambang batas LiLA lebih tinggi dari hasil analisis ambang batas yang diperoleh secara nasional meliputi Sulawesi Utara dan Gorontalo $(25,95 \mathrm{~cm})$. Berdasarkan jumlah daerah tertinggal, sarana kesehatan, dan daya beli masyarakat, provinsi tersebut tidak jauh berbeda dengan provinsi yang memiliki ambang batas di bawah ambang batas nasional. Ambang batas yang optimal di provinsi tersebut dapat disebabkan oleh pola hidup penduduk wanita yang terkait pola konsumsi lemak dan aktivitas fisik yang berkaitan dengan LiLA, diukur dengan jumlah lemak bawah kulit (Persamaan 1).

Hasil analisis persamaan garis prediksi IMT tersebut
Tabel 3. Perbandingan Ambang Batas Hasil Analisis dengan yang Digunakan Kementerian Kesehatan Republik Indonesia

\begin{tabular}{|c|c|c|}
\hline \multirow{2}{*}{ Analisis } & \multicolumn{2}{|c|}{ Ambang Batas LiLA } \\
\hline & $\begin{array}{c}\text { Hasil Analisis } \\
(24,95 \mathrm{~cm})\end{array}$ & $\begin{array}{c}\text { Kemenkes RI } \\
(23,50 \mathrm{~cm})\end{array}$ \\
\hline $\mathrm{Se}(\%)$ & 85 & 63 \\
\hline $\mathrm{Sp}(\%)$ & 75 & 92 \\
\hline NPP $(\%)$ & 20 & 34 \\
\hline NPN $(\%)$ & 99 & 97 \\
\hline $\mathrm{LR}+$ & 3,07 & 5,67 \\
\hline LR- & 0,32 & 0,54 \\
\hline
\end{tabular}

Persamaan 1

$\mathrm{IMT}^{*}=14,946+0,815 * \mathrm{LiLA}+0,04 * \mathrm{U}-0,097 * \mathrm{~TB}$

Keterangan :

*standar eror $\quad=2,6357$

koefisien determinasi $=0,505$

menunjukkan bahwa terdapat hubungan linier antara ukuran LiLA dan umur dengan IMT. Artinya, IMT akan bertambah bila ukuran LiLA bertambah $1 \mathrm{~cm}$ dan umur bertambah 1 tahun. Berdasarkan hasil analisis untuk nasional, ukuran LiLA, tinggi badan, dan umur dapat menjelaskan variasi variabel IMT sebesar 50,5\%. Artinya, variabel LiLA, umur, dan tinggi badan berperan sebanyak $50,5 \%$ dalam menjelaskan IMT. Sisanya, sebanyak $49,5 \%$ dijelaskan oleh variabel lain yang terkait. Berdasarkan hasil analisis penelitian ini diketahui bahwa di Indonesia setiap kenaikan $1 \mathrm{~cm}$ ukuran LiLA seorang wanita akan meningkatkan nilai IMT sebanyak 0,815 $\mathrm{kg} / \mathrm{m}^{2}$ setelah dikontrol dengan umur dan tinggi badan. Pada ibu dengan umur yang lebih tua, IMT akan lebih besar sebanyak $0,04 \mathrm{~kg} / \mathrm{m}^{2}$ setelah dikontrol dengan variabel LiLA dan tinggi badan. Namun, pada ibu yang memiliki ukuran tubuh lebih tinggi, nilai IMT lebih rendah sebanyak $0,097 \mathrm{~kg} / \mathrm{m}^{2}$ setelah dikontrol dengan ukuran LiLA dan umur.

Selain hasil analisis persamaan garis prediksi IMT secara nasional, dilakukan juga analisis per provinsi untuk mengetahui kontribusi LiLA, tinggi badan, dan umur terhadap IMT di setiap provinsi di Indonesia. Berdasarkan hasil analisis, diperoleh kontribusi LiLA, tinggi badan, dan umur terbesar dalam menjelaskan IMT terdapat di Provinsi Sulawesi Utara, DKI Jakarta, dan DI Yogyakarta dengan koefisien determinasi sebesar $61 \%$ dan yang terendah terdapat di Provinsi Jambi dengan koefisien determinasi sebesar 37\%. Artinya, untuk Provinsi Sulawesi Utara, DKI Jakarta, dan DI Yogyakarta perhitungan IMT dalam mendeteksi ibu hamil dengan status gizi prahamil KEK sebesar $61 \%$ dijelaskan oleh LiLA, tinggi badan, dan umur, sedangkan di Provinsi Jambi kontribusi pengukuran tersebut hanya $37 \%$. Nilai konstanta IMT terbe- 
sar adalah Provinsi Maluku $(23,702)$ dan terendah Provinsi Kalimantan Selatan (9,690). Hal tersebut berarti bahwa jika tanpa kontribusi LiLA dan dikontrol dengan tinggi badan dan umur, nilai IMT di Provinsi Maluku ialah 23,70 kg/m² sedangkan di Provinsi Kalimantan Selatan hanya sebesar 9,69 kg/ $\mathrm{m}^{2}$. Namun, setelah dianalisis kontribusi LiLA, tinggi badan, dan umur pada persamaan garis prediksi IMT tersebut, tidak terdapat pola yang jelas terkait kondisi rata-rata LiLA, tinggi badan, dan umur pada setiap provinsi tersebut. Dengan begitu, persamaan garis prediksi IMT untuk Indonesia dapat digunakan sebagai formula untuk seluruh provinsi di Indonesia.

\section{Pembahasan}

LiLA merupakan pengukuran status gizi yang lebih mudah dan praktis karena hanya menggunakan satu alat ukur yaitu pita pengukur LiLA. Namun, LiLA hanya dapat digunakan untuk keperluan skrining, tidak untuk pemantauan. Khusus pada wanita hamil, LiLA digunakan untuk mengetahui risiko KEK karena pada umumnya wanita Indonesia tidak mengetahui berat badan pralahir, sehingga IMT prahamil tidak dapat diukur. Pengukuran IMT membutuhkan 2 alat yaitu timbangan dan pengukur tinggi badan yang membutuhkan persyaratan tertentu yang harus dipenuhi seperti kalibrasi alat timbang serta lantai yang keras dan datar untuk pengukuran tinggi badan. Namun, IMT tidak dapat digunakan sebagai indikator KEK ibu hamil karena perubahan berat badan yang terjadi selama kehamilan. Oleh sebab itu, LiLA bermanfaat untuk pengukuran risiko KEK pada ibu hamil karena LiLA relatif stabil.

Hasil analisis korelasi menunjukkan bahwa LiLA berhubungan erat dengan IMT (koefisien korelasi berkisar pada rentang $0,51-0,75)$. Hasil penelitian ini sesuai dengan beberapa penelitian serupa oleh Krasovec, ${ }^{14}$ Bose et al, ${ }^{20}$ Dasgupta, ${ }^{21}$ dan Chakraborty et al, ${ }^{11}$ di India, serta penelitian oleh Khadivzadeh, ${ }^{22}$ di Iran. Oleh sebab itu, analisis ambang batas LiLA dapat dilakukan dengan menggunakan IMT sebagai gold standard.

Kurva ROC merupakan ringkasan hasil nilai sensitivitas dan spesifisitas untuk berbagai ambang batas, dalam hal ini ambang batas ukuran LiLA. Pada performa kurva ROC dilihat dari AUC, semakin mendekati nilai 1 performa tersebut semakin baik. Nilai AUC sama dengan 1 berarti performa kurva ROC tersebut sangat akurat. 17,19

Hasil penelitian ini sejalan dengan hasil penelitian sebelumnya oleh Herawati, ${ }^{15}$ terkait sensitivitas dan spesifisitas ambang batas LiLA pada titik $23,5 \mathrm{~cm}$ pada WUS di Indonesia. Penelitian tersebut lebih mengarah pada kejadian bayi BBLR. ${ }^{15}$ Penelitian Lechtig di Brazil juga diperoleh hasil ambang batas $23,5 \mathrm{~cm}$ mempunyai nilai $\mathrm{Se}=77 \%$ dan $\mathrm{Sp}=71 \%$ atau tergolong baik untuk mem- prediksi bayi BBLR. ${ }^{14}$ Nilai sensitivitas yang tinggi diperlukan dalam suatu uji diagnostik untuk mendeteksi kasus yang serius. Nilai spesifisitas diperlukan jika perawatan atau pengobatan berikutnya untuk kasus tersebut berisiko tinggi. Kejadian KEK merupakan salah satu kasus yang serius karena berdampak jangka panjang serius dan memengaruhi daur kehidupan. ${ }^{17}$

Kementerian Kesehatan Republik Indonesia mengungkapkan bahwa wanita yang mengalami KEK pada usia subur dan ibu hamil berdampak pada proses melahirkan dan berat lahir bayi serta kemungkinan mengalami kesulitan persalinan, perdarahan, dan berpeluang melahirkan bayi BBLR yang dapat menyebabkan kematian ibu atau bayi. Sesuai dengan hasil Survei Demografi Kesehatan Indonesia (SDKI) tahun 2002 2003, bayi BBLR merupakan penyebab kematian neonatal tertinggi. 23

Selain itu, terkait dengan daur kehidupan, siklus hitam dalam daur kehidupan dapat diputus dengan pencegahan risiko KEK pada wanita sejak usia dini. Dengan demikian, risiko melahirkan bayi BBLR dapat dicegah sehingga menurunkan angka balita kekurangan energi protein agar tumbuh menjadi remaja, dewasa, dan lanjut usia yang berstatus gizi baik. Selain KEK merupakan masalah yang serius, perawatan lanjutan pada wanita KEK tidak berisiko buruk, sebaliknya menguntungkan sebab dianjurkan makan makanan yang bergizi baik.

Berdasarkan analisis nilai likelihood ratio positive, ambang batas 23,5 cm lebih baik karena lebih spesifik dalam mengenali kasus. Namun, pada penggunaan ambang batas $23,5 \mathrm{~cm}$ masih terdapat kemungkinan beberapa kasus yang sebenarnya KEK tetapi tidak terdeteksi berisiko KEK, lebih besar dibandingkan dengan ambang batas 24,95 cm. Hal ini dapat berakibat fatal jika orang yang tidak terdeteksi berisiko KEK tersebut sangat membutuhkan penanganan lebih lanjut. Oleh sebab itu, lebih diutamakan mendapatkan kasus risiko KEK sebanyak-banyaknya agar dapat ditangani lebih lanjut sehingga uji diagnostik yang lebih diperlukan ialah yang mempunyai nilai sensitivitas yang tinggi meskipun spesifisitasnya rendah. Jadi, berdasarkan analisis sensitivitas, spesifisitas, ambang batas $24,95 \mathrm{~cm}$ merupakan ambang batas yang tepat untuk mendeteksi risiko KEK. Dengan demikian, hasil penelitian ini menunjukkan bahwa untuk mendeteksi risiko KEK pada wanita usia 20 45 tahun yang tidak hamil sebaiknya tidak menggunakan ambang batas $23,5 \mathrm{~cm}$, tetapi 24,95 $\mathrm{cm}$. Dengan demikian, dari segi program, ambang batas $24,95 \mathrm{~cm}$ dapat dijadikan peringatan sasaran program untuk menurunkan risiko KEK pada WUS.

Selain analisis ambang batas optimal LiLA seIndonesia, dilakukan juga analisis ambang batas optimal LiLA pada 33 provinsi yang tersebar di pulau-pulau besar Indonesia. Berdasarkan hasil analisis, mayoritas am- 
bang batas optimal LiLA terhadap IMT di 33 provinsi ialah $\pm 25 \mathrm{~cm}$. Nilai ini hampir sama dengan hasil analisis ambang batas optimal LiLA untuk nasional yaitu $24,95 \mathrm{~cm}$. Hasil analisis per provinsi ini menunjukkan bahwa hasil ambang batas LiLA yang diperoleh untuk nasional $(24,95 \mathrm{~cm})$ cukup mewakili ambang batas LiLA yang optimal untuk seluruh wanita usia $20-45$ tahun di setiap provinsi. Meskipun ambang batas optimal hampir semua provinsi berada pada titik $25 \mathrm{~cm}$, terdapat beberapa provinsi yang mempunyai ambang batas berbeda, lebih rendah atau lebih tinggi dari ambang batas hasil analisis nasional.

Banyak hal yang dapat memengaruhi perbedaan ambang batas optimal LiLA. Keragaman ambang batas di Indonesia tersebut sesuai dengan hasil penelitian sebelumnya bahwa bentuk tubuh orang dewasa Indonesia yang lebih beragam mungkin disebabkan oleh ragam suku atau etnik yang banyak di Indonesia serta riwayat gizi masa kanak-kanak yang tidak sama. ${ }^{24}$ Etnik yang berbeda mempunyai pola pembentukan lemak yang berbeda pula. Pernyataan ini dijelaskan Vogel dan Friede, ${ }^{25}$ bahwa pada etnik yang berbeda terdapat beberapa perbedaan yaitu perbedaan distribusi lemak dan massa otot.

Berdasarkan data Profil Kesehatan Indonesia tahun 2010, fakta geografis Indonesia yang unik tersebut menyebabkan Indonesia mempunyai keragaman budaya, adat istiadat, dan suku atau etnik dengan karakteristik yang berbeda satu sama lain. Keragaman budaya, adat istiadat, dan etnik yang berbeda memungkinkan perbedaan distribusi lemak dan massa otot yang menyebabkan perbedaan kecenderungan ukuran LiLA sehingga berpengaruh terhadap ambang batas LiLA yang optimal pada wanita di berbagai provinsi Indonesia. Perbedaan kecenderungan pola hidup dan pola pembentukan lemak terjadi pada warga di berbagai provinsi di Indonesia seperti Sulawesi Utara dan Gorontalo. Kedua provinsi tersebut mempunyai konsumsi lemak pada penduduk dewasa wanita lebih besar dibanding penduduk pria. Provinsi Gorontalo mempunyai pola konsumsi makanan berlemak tertinggi yaitu 25,8\%, lebih tinggi dibanding angka nasional 12,8\% sedangkan di Sulawesi Utara tidak lebih tinggi dari angka nasional. Namun, hampir setengah penduduk khususnya wanita di Sulawesi Utara mempunyai aktivitas fisik yang rendah. Di Gorontalo, secara umum penduduk tersebut mempunyai aktivitas yang cukup atau sedang, tetapi dengan prevalensi aktivitas kurang pada penduduk wanita $(56,3 \%)$ lebih tinggi daripada pria $(35,2 \%)$. Data-data tersebut menunjukkan bahwa status gizi wanita di Sulawesi Utara berhubungan dengan aktivitas fisik yang rendah sedangkan di Gorontalo berkaitan dengan pola konsumsi makanan berlemak tinggi.

Pola hidup di wilayah tersebut berpengaruh karena terkait dengan aktivitas fisik. Semakin modern kehidupan di suatu wilayah, semakin berkurang aktivitas fisik penduduk di wilayah tersebut. Hal tersebut disebabkan oleh modernisasi yang cenderung memberikan kemudahan pada setiap orang sehingga aktivitas menjadi berkurang dan menyebabkan massa lemak bertambah karena energi dari makanan disimpan sebagai lemak cadangan.

Pembentukan lemak tersebut berkontribusi pada peningkatan ukuran LiLA. Selain itu, kemajuan perekonomian di suatu wilayah juga berpengaruh terhadap perbedaan status gizi atau ambang batas optimal LiLA di wilayah tersebut. Menurut Kementerian Kesehatan Republik Indonesia, hal ini disebabkan oleh perekonomian yang berpengaruh terhadap kemampuan daya beli masyarakat dalam memenuhi kebutuhan kesehatan dan pangan sehari-hari. Kemampuan pemenuhan kesehatan dan pangan ini akan berkaitan dengan status gizi yang dapat dideteksi melalui ukuran LiLA. Perbedaan nilai ambang batas ini juga terjadi di Nigeria.

Beberapa provinsi yang mempunyai ambang batas berbeda ialah Provinsi Nusa Tenggara Timur dan Papua dengan ambang batas terendah yaitu 1 angka lebih rendah daripada ambang batas hasil analisis nasional pada titik $24 \mathrm{~cm}$. Berdasarkan fakta tersebut terlihat bahwa provinsi yang mempunyai ambang batas optimal lebih rendah tersebut memiliki banyak daerah tertinggal.

Mayoritas pekerjaan wanita di kedua provinsi tersebut adalah ibu rumah tangga dan buruh tani. Daerah tertinggal belum terpengaruh modernisasi dan kemudahan di berbagai aspek ditambah dengan mayoritas pekerjaan pada wanita di provinsi tersebut berpengaruh terhadap aktivitas. Wanita di provinsi tersebut mempunyai kecenderungan aktivitas yang tinggi sehingga pola pembentukan lemak menjadi lebih rendah dibandingkan dengan pembentukan otot.

Selain ambang batas optimal LiLA di seluruh Indonesia, penelitian ini juga memperoleh persamaan garis prediksi IMT yang dianalisis berdasarkan ukuran LiLA dikontrol dengan tinggi badan dan umur. Analisis ini dilakukan untuk mengetahui kontribusi LiLA, tinggi badan, dan umur dalam menjelaskan IMT terkait pendeteksian status gizi ibu prahamil tergolong KEK. Pada ibu yang tidak mengetahui berat badan saat sebelum hamil, persamaan garis prediksi IMT dapat membantu mengetahui status gizi dengan cara mengukur LiLA dan tinggi badan serta mengetahui umurnya.

Penggunaan LiLA untuk mengetahui status gizi prahamil melalui IMT ini disebabkan hubungan yang kuat antara keduanya dan kemampuan kedua pengukuran tersebut sebagai indikator status gizi pada wanita dewasa. Selain itu, berdasarkan penelitian diperoleh hasil bahwa LiLA mempunyai ukuran yang relatif stabil selama kehamilan dan merupakan satu-satunya pengukuran 
yang mungkin diperlukan untuk mengidentifikasi wanita hamil dengan risiko hasil kelahiran yang buruk. ${ }^{14}$ Ditemukan juga bahwa ukuran LiLA wanita di Indonesia selama kehamilan hanya berubah sebanyak 0,4 $\mathrm{cm}$. Perubahan LiLA selama kehamilan ini tidak terlalu besar sehingga pengukuran LiLA pada massa kehamilan masih dapat dilakukan untuk melihat status gizi ibu sebelum hamil.

\section{Kesimpulan}

Rata-rata berat badan berada pada kisaran 44,24 $62,70 \mathrm{~kg}$ dan rata-rata tinggi badan berada pada rentang 146,56 - 158,34 cm. Rata-rata IMT wanita Indonesia usia 20 - 45 tahun berada pada kisaran 19,24 - 26,74 $\mathrm{kg} / \mathrm{m}^{2}$. Prevalensi wanita KEK berdasarkan IMT pada wanita usia 20 - 45 tahun di Indonesia ialah 6,7\%. Ratarata ukuran LiLA wanita usia 20 - 45 tahun di Indonesia berkisar antara 23,37 $\mathrm{cm}-29,67 \mathrm{~cm}$ dan prevalensi wanita berisiko KEK berdasarkan LiLA $23,5 \mathrm{~cm}$ pada wanita usia 20 - 45 tahun di Indonesia ialah 12,4\%. Ambang batas LiLA yang mempunyai nilai sensitivitas dan spesifisitas paling optimal dan berkorelasi dengan ambang batas IMT $\left(<18,5 \mathrm{~kg} / \mathrm{m}^{2}\right)$ dalam mendeteksi risiko KEK pada WUS di Indonesia ialah $24,95 \mathrm{~cm}(\mathrm{Se}=$ $85 \%$ dan $\mathrm{Sp}=75 \%$ ). Prevalensi wanita berisiko KEK berdasarkan LiLA $24,95 \mathrm{~cm}$ pada wanita usia $20-45$ tahun di Indonesia ialah 27,5\%. Berdasarkan uji kemaknaan, semua perhitungan mempunyai hubungan yang bermakna (nilai $\mathrm{p}<0,000$ ). Semua hubungan antarpengukuran dengan LiLA mempunyai pola positif. Berdasarkan uji korelasi, variabel LiLA mempunyai hubungan yang kuat dengan IMT $(r=0,67)$ dan berat badan $(r=0,66)$ sedangkan LiLA mempunyai hubungan yang sangat lemah dengan umur $(r=0,23)$ dan tinggi badan $(r=0,07)$. Mayoritas ambang batas LiLA dengan nilai sensitivitas dan spesifisitas paling tinggi di 33 provinsi Indonesia berada pada titik $24,95 \mathrm{~cm}$ atau 25 $\mathrm{cm}$. Namun, terdapat beberapa provinsi yang memiliki ambang batas LiLA berbeda. Provinsi yang mempunyai ambang batas LiLA 0,5-1 cm di bawah ambang batas nasional ialah Nusa Tenggara Timur $(23,95 \mathrm{~cm})$ dan Papua $(24,05 \mathrm{~cm})$. Provinsi yang mempunyai ambang batas LiLA di atas ambang batas nasional ialah Sulawesi Utara dan Gorontalo $(25,95 \mathrm{~cm})$. Oleh sebab ambang batas LiLA di antara ke-33 provinsi di Indonesia tidak jauh berbeda maka ambang batas $24,95 \mathrm{~cm}$ dapat digunakan sebagai ambang batas nasional. LiLA, tinggi badan, dan umur mempunyai kontribusi yang cukup baik yaitu 50,5\% dalam menjelaskan IMT. Artinya, setiap kenaikan LiLA sebesar $1 \mathrm{~cm}$ akan meningkatkan nilai IMT sebanyak $0,815 \mathrm{~kg} / \mathrm{m}^{2}$. Setiap 1 tahun kenaikan umur wanita akan menaikkan nilai IMT sebanyak $0,04 \mathrm{~kg} / \mathrm{m}^{2}$ dan setiap kenaikan $1 \mathrm{~cm}$ tinggi badan wanita akan menurunkan nilai IMT sebesar $0,097 \mathrm{~kg} / \mathrm{m}^{2}$. Persamaan garis prediksi IMT berdasarkan LiLA dengan dikontrol oleh variabel tinggi badan dan umur di 33 provinsi Indonesia berbeda-beda dan tidak mempunyai pola terhadap ketiga variabel tersebut (LiLA, tinggi badan, dan umur) sehingga persamaan garis prediksi IMT nasional dapat digunakan di berbagai provinsi di Indonesia untuk mengetahui status gizi ibu sebelum hamil.

\section{Saran}

Disarankan untuk membedakan fungsi penggunaan ambang batas LiLA $24,95 \mathrm{~cm}$ untuk mendeteksi risiko KEK wanita usia 20 - 45 tahun, sementara $23,5 \mathrm{~cm}$ untuk outcome kehamilan yakni morbiditas dan mortalitas bayi.

\section{Daftar Pustaka}

1. Kementerian Kesehatan Republik Indonesia. Penggunaan alat ukur lingkar lengan atas (LiLA) pada wanita usia subur (WUS). Jakarta: Kementerian Kesehatan Republik Indonesia; 1994.

2. Ningrum RAV. Faktor-faktor yang berhubungan dengan risiko kurang energi kronis pada wanita usia subur di Kelurahan Mampang Pancoran Mas, Depok tahun 2010 [skripsi]. Depok: Fakultas Kesehatan Masyarakat Universitas Indonesia; 2011.

3. Syofianti H. Pengaruh risiko kurang energi kronis pada ibu hamil terhadap berat badan bayi lahir rendah (analisis kohort ibu di Kabupaten Sawahlunto-Sijujung tahun 2007) [tesis]. Depok: Fakultas Kesehatan Masyarakat Universitas Indonesia; 2008.

4. Kementerian Kesehatan Republik Indonesia. Laporan hasil riset kesehatan dasar di Indonesia. Jakarta: Kementerian Kesehatan Republik Indonesia; 2007.

5. Kementerian Kesehatan Republik Indonesia. Gizi dalam angka sampai dengan 2002; surveilans gizi, direktorat gizi masyarakat; dan profil kesehatan reproduksi. Jakarta: Kementerian Kesehatan Republik Indonesia; 2003.

6. United Nation Emergency Children's Fund. A UNICEF policy review: strategy for improved nutrition of children and women in developing countries. New York; 1997. p. 20-22.

7. Andert CU, Sanchaisuriya P, Sanchaisuriya K, Schelp FP, Schweigert FJ. Nutritional status of pregnant women in Northeast Thailand. Asian Pacific Journal of Clinical Nutrition. 2006; 15 (3): 329-34.

8. Administrative Committee on Coordination/Standing Committee on Nutrition $(\mathrm{ACC} / \mathrm{SCN})$. Fourth report of the world nutrition situation. Geneva: United Nations; 2002. Available from: http://www.fao.org.

9. Gibson R. Principle of nutritional assessment. 2nd ed. New York: Oxford University Press; 2005.

10. Sebire NJ, Jolly M, Harris J, Regan L, Robinson S. Is maternal underweight really is risk factor for adverse pregnancy outcome. BJOG: An International Journal of Obstetrics and Gynaecology. 2001; 108 (1): 616.

11. Chakraborty R, Bose K, Koziel S. Use of mid-upper arm circumference as a measure of nutritional status and its relationship with self reported morbidity among adult Bengalee male Slum Dwellers Of Kolkata, India. Anthropolgischer Anzeiger. 2009; 67 (2): 129-137.

12. Kementerian Kesehatan Republik Indonesia. Pedoman praktis peman- 
tauan status gizi orang dewasa. Jakarta: Kementerian Kesehatan Republik Indonesia; 2002.

13. Supariasa, Nyoman ID, Bakri B, Fajar I. Penilaian status gizi. . Jakarta: Penerbit Buku Kedokteran EGC; 2002.

14. Krasovec K, Anderson MA. Maternal nutrition and pregnancy outcomes. USA: Pan American Health Organization; 1991.

15. Herawati. Indeks lingkar lengan atas (LiLA), indeks status gizi lainnya dan faktor-faktor ibu serta hubungannya dengan berat badan bayi lahir di Kecamatan Gabus Wetan dan Sliyeg, Kabupaten Indramayu, Jawa Barat, 1990 - 1993 [tesis]. Depok: Fakultas Kesehatan Masyarakat UI; 1993.

16. Olukoya AA. Identification of underweight women by measurement of the arm circumference. International journal of gynaecology and obstetrics: the official organ of the International Federation of Gynaecology and Obstetrics. 1990; 31: 231-5.

17. Ho PS, Mo GJ, Jo CH. Receiver operating characteristic (ROC) curve: practical review for radiologists. Korean Journal Radiology. 2004; 15 : 11-18.

18. Metz CE. Basic principles of ROC analysis. Seminars in Nuclear Medicine. 1978; 8: 283-98.

19. Obuchowski NA. Receiver operating characteristic curves and their use in radiology. Radiology. 2003; 229: 3-8.

20. Bose K, Bisai S, Das P, Diksit P, Pradhan S. Relationship of income with anthropometrics indicators of chronic energy deficiency among adults female Slem Dwellers Of Midnapore Town, India. Journal Human Ecology. 2007; 22 (2): 171-176.

21. Dasgupta A, Butt A, Saha TK, Basu G, Chattopadhyay A, Mukherjee A. 2009. Assessment of malnutrition among adolescents: can BMI be replaced by MUAC. Department of Community Medicine, A.I.I.H \&.H, 110 C.R. Avenue, Kolkata-700 073, India. Indian Journal of Community Medicine. 2010; 35 (2): 276-9.

22. Khadivzadeh T. Mid upper arm and calf circumferences as indicators of nutritional status in women of reproductive age. Eastern Mediterranean Health Journal. 2001 [cited 2002 September]; 8 (4 \& 5). Available from: http://www.emro.who.int.

23. Kementerian Kesehatan Republik Indonesia. Profil kesehatan Indonesia 2004. Jakarta: Kementerian Kesehatan Republik Indonesia; 2005.

24. Fatmah. Diagnostic test of predicted height model in Indonesian elderly: study in an urban area. Medical Journal of Indonesia. 2010; 19 (3): 199-204.

25. Vogel JA, Friedl KE. Body fat assessment in women: special consideration. Sport Medicine. 1992; 13 (4): 245-69. 